\title{
Influence of Fish Bone Meal on Performance of Soybean (Glycine max L.) in Sandy Loam Soils of Chikkamagaluru District of Karnataka
}

\author{
L.N. Cheluvaraj ${ }^{1 *}$, B.C. Dhananjaya ${ }^{1}$, M. Ashok, \\ H.K. Veeranna and H.M. Chidanandappa
}

${ }^{1}$ Department of Soil Science and Agricultural Chemistry, University of Agricultural and Horticultural Sciences, Shivamogga, India

${ }^{2}$ Krishi Vignana Kendra, Shivamogga, University of Agricultural and Horticultural Sciences, Shivamogga, India

${ }^{3}$ Department of Agronomy, College of Agriculture, University of Agricultural and Horticultural Sciences, Shivamogga, India

*Corresponding author

\section{A B S T R A C T}

Keywords

Fish bone meal (FBM), Soybean,

Phosphorus

solubilizing bacteria (PSB)

Article Info

Accepted:

17 September 2020 Available Online: 10 October 2020
A field experiment was conducted at Agricultural and Horticultural Research Station (AHRS), Bavikere, Chikkamagaluru during Rabi 2019 to study the effect of fish bone meal on performance of soybean (Glycine max L.). Ten treatment combinations with three replications in a randomized complete block design (RCBD) was followed in the experiment. The recommended dose of $\mathrm{N}, \mathrm{P}$ and $\mathrm{K}$ were applied through fish bone meal (FBM) and mineral fertilizer at 0, 25, 50, 75 and 100 per cent levels with or without PSB seed treatment along with recommended dose of FYM. Application of 25 per cent of recommended P through FBM and remaining through mineral fertilizer with PSB seed treatment significantly increased the growth, yield attributes and grain yield $\left(26.15 \mathrm{q} \mathrm{ha}^{-1}\right)$ and stover yield (43.73 $\mathrm{q} \mathrm{ha}^{-1}$ ) of soybean.

\section{Introduction}

Fish bone meal (FBM) is a product made from the bones and leftover of fish caught by commercial fisheries. FBM is obtained by drying the fish or fish trimmings followed by grinding and it finally takes the form of powder or cake. Fish bone meal consists of about 50 per cent protein, 35 per cent ash, 8 to 12 per cent of fat and 4 to 7 per cent moisture. It contains approximately 6 per cent nitrogen, 5 per cent phosphorus, 0.2 per cent potassium, 11 to 15 percent of calcium, 0.19 to 0.25 per cent of magnesium and 0.2 to 0.4 per cent of 
sulphur. The average organic matter content is 20 to 25 per cent. The phosphorus content of FBM varies from 5 to 9 per cent, is mostly influenced by the bone content of raw material. Most of the FBM-P is present as calcium phosphate $\left[\mathrm{Ca}_{5}\left(\mathrm{PO}_{4}\right)_{3} \mathrm{OH}\right]$ in the bone fraction and organic form in the meat fraction. However, due to its chemical nature, $\mathrm{P}$ in FBM is classified as sparingly soluble (readily plant available content 19-40 \%) (Lee et al., 2010).

Phosphorus solubilizing biofertilizers are carrier-based preparations containing living or dormant cells of micro-organisms like bacteria, fungi and actinomycetes. These micro-organisms help in increasing crop production by solubilization of insoluble phosphorus and increase plant growth by providing nutrients, vitamins and other growth factors (Gaur and Sunita, 1999). Fish bone meal in the presence of biofertilizers and soil micro-flora in the soil is acted upon by certain organic acids. It releases phosphorus in the form of available monocalcium phosphate.

Leguminous soybean requires phosphorus, calcium and sulphur for root growth, nodule formation, protein and oil synthesis. Slow release phosphatic fertilizer like FBM, a cheap source of phosphorus to plants can be exploited with the mineral fertilizers along with PSB to increase phosphorus use efficiency, crop yield and soil health.

\section{Materials and Methods}

A field experiment was conducted at Agricultural and Horticultural Research Station (AHRS), Bavikere, UAHS, Shivamogga during Rabi season of 2019 to study the 'Effect of fish bone meal on the performance of soybean (Glycine max L.)'. The research station comes under Southern Transition Agro-climatic Zone (Zone-VII) of
Karnataka. It is situated at $13^{\circ} 42^{\circ} \mathrm{N}$ latitude and $75^{\circ} 51^{\circ} \mathrm{E}$ longitude and an altitude of 695 meters above mean sea level. The average rainfall of the zone is $1193.8 \mathrm{~mm}$. Prior to the initiation of experiment, composite soil sample from experimental area were collected from 0 to $15 \mathrm{~cm}$ depth and analyzed for physical and chemical properties using standard procedures (Table 1).

The recommended of FYM, N, P and $\mathrm{K}$ were applied through the fish bone meal and mineral fertilizer at $0,25,50,75$ and 100 per cent with or without PSB seed treatment. Ten treatment combinations were used in RCBD with three replications viz., RDF NPK $\left(\mathrm{T}_{1}\right)$, $\mathrm{RDF} \mathrm{NPK}+\mathrm{PSB}\left(\mathrm{T}_{2}\right), \mathrm{RDF} \mathrm{NK}+25 \% \mathrm{P}$ through $\mathrm{FBM}+75 \%$ RDP $\left(\mathrm{T}_{3}\right), \mathrm{RDF} \mathrm{NK}+$ $25 \% \mathrm{P}$ through $\mathrm{FBM}+75 \% \mathrm{RDP}+\mathrm{PSB}\left(\mathrm{T}_{4}\right)$, $\mathrm{RDF} \mathrm{NK}+50 \% \mathrm{P}$ through $\mathrm{FBM}+50 \% \mathrm{RDP}$ $\left(\mathrm{T}_{5}\right), \mathrm{RDF} \mathrm{NK}+50 \% \mathrm{P}$ through $\mathrm{FBM}+50 \%$ $\mathrm{RDP}+\mathrm{PSB}\left(\mathrm{T}_{6}\right), \mathrm{RDF} \mathrm{NK}+75 \% \mathrm{P}$ through $\mathrm{FBM}+25 \% \mathrm{RDP}\left(\mathrm{T}_{7}\right), \mathrm{RDF} \mathrm{NK}+75 \% \mathrm{P}$ through $\mathrm{FBM}+25 \% \mathrm{RDP}+\mathrm{PSB}\left(\mathrm{T}_{8}\right), \mathrm{RDF}$ $\mathrm{NK}+100 \% \mathrm{P}$ through FBM $\left(\mathrm{T}_{9}\right), \mathrm{RDF} \mathrm{NK}+$ $100 \% \mathrm{P}$ through FBM + PSB $\left(\mathrm{T}_{10}\right)$.

The experimental soil was sandy loam in texture having $\mathrm{pH} 5.56$, bulk density $1.37 \mathrm{gm}^{-}$ ${ }^{3}$, EC $0.11 \mathrm{dsm}^{-1}$ with organic carbon content of $9.10 \mathrm{~g} \mathrm{~kg}^{-1}$. Further, the soil was low in nitrogen $\left(246.90 \mathrm{~kg} \mathrm{ha}{ }^{-1}\right)$, medium in phosphorus status (48.50 kg ha ${ }^{-1}$ ) and medium in available potassium status (266.40 $\left.\mathrm{kg} \mathrm{ha}^{-1}\right)$.

Total elemental composition of fish bone meal is presented in Table 2. The $\mathrm{pH}$ of fish bone meal was 6.13 with electrical conductivity of $0.95 \mathrm{dS} \mathrm{m} \mathrm{m}^{-1}$ and the total $\mathrm{C}$ content was 21.09 per cent. The concentration of total nitrogen, phosphorus and potassium were $6.20,5.10$ and 0.23 per cent, respectively. FBM contains total calcium, magnesium and sulphur to the extent of 9.47, 0.29 and 0.43 per cent, respectively. The concentration of iron, manganese, zinc and 
copper were $42.00,113.00,0.60$ and 17.10 $\mathrm{mg} \mathrm{kg}{ }^{1}$, respectively

Calculated quantity of fishbone meal and FYM were applied per plot as per the treatments seven days before sowing of crop.The recommended dose of nutrients for soybean used was $30 \mathrm{~kg} \mathrm{~N}, 80 \mathrm{~kg} \mathrm{P}_{2} \mathrm{O}_{5}$ and $37.5 \quad \mathrm{~kg} \quad \mathrm{~K}_{2} \mathrm{O} \quad \mathrm{kg} \quad \mathrm{ha}^{-1}$. Nitrogen and phosphorus were applied through urea and SSP while potash was applied using muriate of potash (MOP) as per calculation. All the fertilizers were applied as basal in the furrows made and mixed with soil before placing the seeds. The contribution of $\mathrm{N}$ and $\mathrm{P}$ from the fish bone meal was taken into consideration during the application of fertilizers.

The soybean seeds were sown in each plot with a spacing of $30 \mathrm{~cm}$ in between the rows and $10 \mathrm{~cm}$ in between the seeds. The seeds were sown at $80 \mathrm{~kg} \mathrm{ha}^{-1}$. For ensuring perfect germination, healthy and good quality seeds were used. Seeds were inoculated with Rhizobium japonicum culture and phosphorus solubilizing bacteria (Pseudomonas striata) at $500 \mathrm{~g} \mathrm{ha}^{-1}$ at the time of sowing. All the biometric observations were recorded at different growth stages and were subjected to analysis.

\section{Results and Discussion}

Biometric parameters: Data recorded on plant height as influenced by fish bone meal application in soybean at different growth stages are given in Table 3. Scrutiny of data indicated that there was no significant variation in plant height of soybean at 30 DAS, whereas, substantial influence was observed at remaining growth stages due to different treatments. Highest plant height $(17.23 \mathrm{~cm})$ at 30 DAS was recorded in treatment $\mathrm{T}_{4}(\mathrm{RDF} \mathrm{NK}+25 \% \mathrm{P}$ through $\mathrm{FBM}+75 \%$ RDP + PSB) followed by $\mathrm{T}_{5}$ $(16.89 \mathrm{~cm}), \mathrm{T}_{2}(16.77 \mathrm{~cm}), \mathrm{T}_{3}(16.71 \mathrm{~cm})$ and
$\mathrm{T}_{2}(16.03 \mathrm{~cm})$. The lowest value of plant height at 30 DAS $(15.74 \mathrm{~cm})$ was recorded $\mathrm{T}_{9}$ followed $\mathrm{T}_{7}(15.92)$.

Fish bone meal application along with mineral fertilizers significantly influenced the plant height at $60 \mathrm{DAS}$. Treatment $\mathrm{T}_{4}$ (RDF $\mathrm{NK}+25 \% \mathrm{P}$ through $\mathrm{FBM}+75 \% \mathrm{RDP}+$ PSB) recorded highest plant height (39.44 $\mathrm{cm}$ ) which was significantly superior over rest of the treatments. The recorded values for subsequent treatments $\mathrm{T}_{3}, \mathrm{~T}_{2}, \mathrm{~T}_{1}, \mathrm{~T}_{6}, \mathrm{~T}_{5}, \mathrm{~T}_{8}$, $\mathrm{T}_{7}$ and $\mathrm{T}_{10}$ are $38.51,36.29,35.88,34.09$, 34.07933 .66 and $32.43 \mathrm{~cm}$, respectively, whereas lowest plant height of $31.66 \mathrm{~cm}$ was recorded with $\mathrm{T}_{9}$.

Maximum plant height was recorded in $\mathrm{T}_{4}$ (RDF NK + 25\% P through FBM + 75\% RDP + PSB) treatment at harvest $(59.74 \mathrm{~cm})$ which was significantly superior over almost all treatments. The recorded values for subsequent treatments $\mathrm{T}_{3}, \mathrm{~T}_{2}, \mathrm{~T}_{1}, \mathrm{~T}_{6}, \mathrm{~T}_{5}, \mathrm{~T}_{8}$, $\mathrm{T}_{7}$ and $\mathrm{T}_{10}$ are 58.55, 57.25, 56.22, 55.07, $54.37, \quad 54.70, \quad 49.97$ and $45.55 \mathrm{~cm}$, respectively, whereas, treatment $\mathrm{T}_{9}$ recorded lowest plant height $(44.00 \mathrm{~cm})$.

The increase in plant height might be due to continuous phosphorus availability from FBM-P application with SSP as it plays an essential role in growth, development and photosynthesis which might have reflected in higher values for plant height as reported by Salve et al., (2010). Increase in soybean plant height was due to increased availability of $\mathrm{N}$, $\mathrm{P}, \mathrm{Ca}$ and their beneficial effects on cell division and multiplication (Madhavi et al., 1997). Mineralization of organic $P$ and solubilization of precipitated $\mathrm{P}$ by the microorganisms enhance the $\mathrm{P}$ availability in soils as also reported by Chen et al., (2006)

The data collected on the number of branches per plant as influenced fish bone meal application in soybean at different growth 
stages are given in Table 3. There was no significant difference found in the number of branches of soybean at 30 DAS. The maximum number of branches per plant of soybean recorded in treatment $\mathrm{T}_{4}(\mathrm{RDF} \mathrm{NK}+$ $25 \% \mathrm{P}$ through FBM $+75 \% \mathrm{RDP}+\mathrm{PSB})$ at all growth stages $(3.87,6.77$ and 7.03 at 30, 60 DAS and harvest, respectively). The treatments $T_{3}, T_{2}, T_{1}, T_{6}$ and $T_{5}$ found on par at 60 DAS and harvest, rest of the treatments showed significantly inferior values. At the same time, the lowest number of branches per plant was observed with $\mathrm{T}_{9}$ treatment (3.23, 5.44 and 5.69 at 30, 60 DAS and harvest, respectively) at all the growth stages.

Significant increase in many branches per plant was noticed due to the application of fish bone meal with mineral fertilizers along with PSB seed treatment. However, treatment $\mathrm{T}_{4}$ (RDF NK $+25 \% \mathrm{P}$ through FBM $+75 \%$ RDP + PSB) recorded a significantly higher number of branches per plant compared to other treatments and was on par with $\mathrm{T}_{3}$ (RDF $\mathrm{NK}+25 \% \mathrm{P}$ through FBM $+75 \%$ RDP), $\mathrm{T}_{2}$ (RDF NPK + PSB) and $\mathrm{T}_{1}$ (RDF NPK). High and continuous availability of phosphorus and its role in growth, development and photosynthesis might have reflected in more numbers of branches per plant. These results are akin with findings of Pal et al., (2010), Kunduet al., (2010) and Patil et al., (2000).

\section{Number of pods}

The maximum number of pods per plant (39.27) of soybean was recorded in treatment received 25 per cent $\mathrm{P}$ through FBM and remaining through mineral fertilizer with PSB seed treatment $\left(\mathrm{T}_{4}\right)$ followed by $\mathrm{T}_{3}(38.68), \mathrm{T}_{2}$ (37.64), $\mathrm{T}_{1}$ (37.19), $\mathrm{T}_{6}$ (36.09), $\mathrm{T}_{5}$ (34.32), $\mathrm{T}_{8}$ (30.55), $\mathrm{T}_{7}$ (30.82) and $\mathrm{T}_{10}$ (31.64). The lowest number of pods per plant (28.99) was observed with $\mathrm{T}_{9}$ treatment, as indicated in Table 4.
Application of 25 per cent of $\mathrm{P}$ through FBM and remaining through mineral fertilizer with PSB seed treatment significantly increased the number of pods per plant and grain yield. Treatment $\left(\mathrm{T}_{4}\right)$ recorded considerably higher pods per plant (23.33). The total number of grains per plant (89.01) was higher in treatment $\mathrm{T}_{4}$ compared to other treatments and was on par with treatment which received 25 per cent of $\mathrm{P}$ through FBM and remaining through mineral fertilizer $\left(\mathrm{T}_{3}\right)$, RDF with PSB seed treatment $\left(T_{2}\right)$ and $\operatorname{RDF}\left(T_{1}\right)$. This may be ascribed to increased $\mathrm{P}$ availability in soil due to fish bone meal application, which in turn influenced the physiological processes that are directly related to nitrogen fixation, photosynthesis and translocation of carbohydrates for pod growth.

\section{Total number of grains}

Perusal of data indicates that the total grains per plant of soybean found significant as influenced by the application of FBM and mineral fertilizer (Table 4). Highest grains per plant of soybean was observed with treatment $\mathrm{T}_{4}$ (89.01) followed by treatment $\mathrm{T}_{3}(87.63)$, which were significantly superior over $\mathrm{T}_{2}, \mathrm{~T}_{1}$, $\mathrm{T}_{6}, \mathrm{~T}_{5}, \mathrm{~T}_{8}, \mathrm{~T}_{7}$ and $\mathrm{T}_{10}$. Lowest total grains per plant of soybean (64.87) were observed with treatment $\mathrm{T}_{9}$. This may be ascribed to increased $\mathrm{P}$ availability in soil due to fish bone meal application, which in turn influenced the physiological processes that are directly related to nitrogen fixation, photosynthesis and translocation of carbohydrates for pod growth.

\section{Test weight}

It is evident from the data (Table 4) that the effect of different treatments on test weight of soybean was found non-significant with the application of fish bone meal. Maximum test weight $(8.70 \mathrm{~g})$ was recorded in treatment $\mathrm{T}_{4}$ (RDF NK $+25 \%$ P through FBM $+75 \%$ RDP 
+ PSB).Application of 25 per cent of phosphorus through FBM and remaining through mineral fertilizer with PSB seed treatment recorded higher values of test weight compared to the use of the only fish bone meal. However, no significant difference in test weight was recorded due to the imposition of the treatments.

\section{Grain and stover yield}

The data revealed that the seed yield of soybean was significantly influenced by various treatments (Table 4). Treatments receiving 25 per cent of recommended $\mathrm{P}$ through FBM and remaining through mineral fertilizer with PSB seed treatment $\left(\mathrm{T}_{4}\right)$ recorded higher seed yield of $26.15 \mathrm{q} \mathrm{ha}^{-1}$. However, this treatment remained statistically on par with treatment $\mathrm{T}_{3}(\mathrm{RDF} \mathrm{NK}+25 \% \mathrm{P}$ through FBM + $75 \%$ RDP $)\left(25.84 \mathrm{q} \mathrm{ha}^{-1}\right), \mathrm{T}_{2}$ (RDF NPK + PSB) $\left(24.99 \mathrm{q} \mathrm{ha}^{-1}\right), \mathrm{T}_{1}(\mathrm{RDF}$ NPK) $\left(24.24 \mathrm{q} \mathrm{ha}^{-1}\right)$ and $\mathrm{T}_{6}(\mathrm{RDF} \mathrm{NK}+50 \%$ $\mathrm{P}$ through FBM + $50 \%$ RDP + PSB) $(24.04 \mathrm{q}$ $\mathrm{ha}^{-1}$ ). The performance of treatments $\mathrm{T}_{5}, \mathrm{~T}_{8}$, $T_{7}$ and $T_{10}$ found significantly inferior to $T_{4}$, whereas $\mathrm{T}_{9}$ treatment recorded lowest grain yield $\left(19.32 \mathrm{q} \mathrm{ha}^{-1}\right)$.

Table.1 Initial soil properties of experimental site

\begin{tabular}{|c|c|}
\hline Physical properties & Value \\
\hline Sand $(\%)$ & 65.14 \\
\hline Silt (\%) & 14.35 \\
\hline Clay (\%) & 20.51 \\
\hline Textural class & Sandy loam \\
\hline Bulk density (Mg m $\left.{ }^{-3}\right)$ & 1.37 \\
\hline MWHC (\%) & 33.65 \\
\hline \multicolumn{2}{|l|}{ Chemical properties } \\
\hline pH $(1: 2.5)$ & 5.56 \\
\hline Electrical conductivity $\left(\mathrm{dS} \mathrm{m}^{-1}\right)(1: 2)$ & 0.11 \\
\hline Organic carbon $\left(\mathrm{g} \mathrm{kg}^{-1}\right)$ & 9.10 \\
\hline Cation exchange capacity $\left[\mathrm{cmol}\left(\mathrm{p}^{+}\right) \mathrm{kg}^{-1}\right]$ & 8.18 \\
\hline \multicolumn{2}{|l|}{ Available macro nutrient status } \\
\hline Available $\mathbf{N}\left(\mathrm{kg} \mathrm{ha}^{-1}\right)$ & 246.90 \\
\hline Available $\mathrm{P}_{2} \mathrm{O}_{5}\left(\mathrm{~kg} \mathrm{ha}^{-1}\right)$ & 48.50 \\
\hline Available $\mathrm{K}_{2} \mathrm{O}\left(\mathrm{kg} \mathrm{ha}^{-1}\right)$ & 266.40 \\
\hline Exchangeable $\mathrm{Ca}\left[\mathrm{cmol}\left(\mathrm{p}^{+}\right) \mathrm{kg}^{-1}\right]$ & 4.38 \\
\hline Exchangeable $\mathrm{Mg}\left[\mathrm{cmol}\left(\mathrm{p}^{+}\right) \mathrm{kg}^{-1}\right]$ & 2.28 \\
\hline Available S (mg kg$\left.{ }^{-1}\right)$ & 20.90 \\
\hline
\end{tabular}


Table.2 Characterization of fish bone meal

\begin{tabular}{|c|c|}
\hline Parameter & Value \\
\hline pH $(1: 10$ w/v $)$ & 6.13 \\
\hline $\operatorname{EC}(1: 10 \mathrm{w} / \mathrm{v})\left(\mathbf{d S m}^{-1}\right)$ & 0.95 \\
\hline \multicolumn{2}{|c|}{ Total nutrient concentration } \\
\hline Total carbon $(\%)$ & 21.09 \\
\hline Nitrogen $(\%)$ & 6.20 \\
\hline Phosphorus (\%) & 5.10 \\
\hline Potassium (\%) & 0.23 \\
\hline Calcium (\%) & 9.47 \\
\hline Magnesium (\%) & 0.29 \\
\hline Sulphur (\%) & 0.43 \\
\hline Iron $\left(\mathrm{mg} \mathrm{kg}^{-1}\right)$ & 42.00 \\
\hline Zinc $\left(\mathrm{mg} \mathrm{kg}^{-1}\right)$ & 113.00 \\
\hline Manganese $\left(\mathrm{mg} \mathrm{kg}^{-1}\right)$ & 0.60 \\
\hline Copper $\left(\mathrm{mg} \mathrm{kg}^{-1}\right)$ & 17.10 \\
\hline
\end{tabular}

Table.3 Effect of fish bone meal on plant height and number of branches at different growth stages of soybean

\begin{tabular}{|c|c|c|c|c|c|c|}
\hline \multirow[t]{2}{*}{ Treatments } & \multicolumn{3}{|c|}{ Plant height (cm) } & \multicolumn{3}{|c|}{ No. of branches } \\
\hline & 30 DAS & 60 DAS & Harvest & 30 DAS & 60 DAS & Harvest \\
\hline$T_{1}:$ RDF NPK & 16.03 & 35.88 & 56.22 & 3.62 & 6.23 & 6.41 \\
\hline$T_{2}:$ RDF NPK + PSB & 16.77 & 36.29 & 57.25 & 3.67 & 6.36 & 6.62 \\
\hline $\begin{array}{l}\text { T }_{3}: \text { RDF NK + 25\% P through FBM + } \\
75 \% \text { RDP }\end{array}$ & 16.71 & 38.51 & 58.55 & 3.71 & 6.65 & 6.80 \\
\hline $\begin{array}{l}\text { T }_{4}: \text { RDF NK + 25\% P through FBM + } \\
75 \% \text { RDP + PSB }\end{array}$ & 17.23 & 39.44 & 59.74 & 3.87 & 6.77 & 7.03 \\
\hline $\begin{array}{l}T_{5}: \text { RDF NK + 50\% P through FBM + } \\
50 \% \text { RDP }\end{array}$ & 16.89 & 34.09 & 54.37 & 3.60 & 5.95 & 6.01 \\
\hline $\begin{array}{l}\text { T }_{6}: \text { RDF NK + 50\% P through FBM + } \\
50 \% \text { RDP + PSB }\end{array}$ & 16.76 & 36.37 & 55.07 & 3.34 & 6.15 & 6.38 \\
\hline $\begin{array}{l}\text { T }_{7}: \text { RDF NK + } 75 \% \text { P through FBM + } \\
25 \% \text { RDP }\end{array}$ & 15.92 & 33.66 & 49.97 & 3.30 & 5.68 & 5.82 \\
\hline $\begin{array}{l}\text { T8: RDF NK + 75\% P through FBM + } \\
25 \% \text { RDP + PSB }\end{array}$ & 16.32 & 34.07 & 54.70 & 3.13 & 5.81 & 6.00 \\
\hline$T_{9}:$ RDF NK + 100\% P through FBM & 15.74 & 31.66 & 44.00 & 3.23 & 5.44 & 5.69 \\
\hline $\begin{array}{l}T_{10}: \text { RDF NK + } 100 \% \text { P through FBM + } \\
\text { PSB }\end{array}$ & 16.22 & 32.43 & 45.55 & 3.31 & 5.80 & 5.94 \\
\hline S.Em. \pm & 0.75 & 1.17 & 1.91 & 0.30 & 0.26 & 0.25 \\
\hline CD @ $(\overline{0.05})$ & NS & 3.47 & 5.69 & NS & 0.78 & 0.75 \\
\hline
\end{tabular}


Table.4 Effect of fish bone meal on yield parameters, yield and quality parameter of soybean

\begin{tabular}{|c|c|c|c|c|c|c|}
\hline \multirow[t]{2}{*}{ Treatments } & \multicolumn{5}{|c|}{ Yield parameters and yield } & \multirow{2}{*}{$\begin{array}{c}\text { Quality } \\
\text { parameter } \\
\text { Crude } \\
\text { protein } \\
(\%)\end{array}$} \\
\hline & $\begin{array}{c}\text { Pods } \\
\text { plant }^{-1} \\
\text { (No.) }\end{array}$ & $\begin{array}{c}\text { Total } \\
\text { grains } \\
\text { plant }^{-1} \\
\text { (No.) }\end{array}$ & $\begin{array}{c}\text { Test } \\
\text { weight } \\
\text { (g) }\end{array}$ & $\begin{array}{c}\text { Grain } \\
\text { yield (q } \\
\left.\text { ha }^{-1}\right)\end{array}$ & $\begin{array}{c}\text { Stover } \\
\text { yield } \\
\left(\mathbf{q} \mathbf{h a}^{-1}\right)\end{array}$ & \\
\hline$T_{1}:$ RDF NPK & 37.19 & 84.32 & 8.51 & 24.24 & 40.67 & 35.83 \\
\hline $\mathrm{T}_{2}:$ RDF NPK + PSB & 37.64 & 85.30 & 8.60 & 24.99 & 41.65 & 36.46 \\
\hline $\begin{array}{l}\mathrm{T}_{3}: \text { RDF NK }+25 \% \text { P through FBM } \\
+75 \% \text { RDP }\end{array}$ & 38.68 & 87.63 & 8.67 & 25.84 & 42.19 & 36.65 \\
\hline $\begin{array}{l}\text { T }_{4}: \text { RDF NK + } 25 \% \text { P through FBM } \\
+75 \% \text { RDP + PSB }\end{array}$ & 39.27 & 89.01 & 8.70 & 26.15 & 43.73 & 37.27 \\
\hline $\begin{array}{l}\mathrm{T}_{5}: \text { RDF NK + 50\% P through FBM } \\
+50 \% \text { RDP }\end{array}$ & 34.32 & 76.34 & 8.66 & 23.34 & 38.26 & 35.00 \\
\hline $\begin{array}{l}\text { T }_{6}: \text { RDF NK + 50\% P through FBM } \\
+50 \% \text { RDP + PSB }\end{array}$ & 36.09 & 81.77 & 8.47 & 24.04 & 40.40 & 36.21 \\
\hline $\begin{array}{l}\text { T }_{7}: \text { RDF NK + } 75 \% \text { P through FBM } \\
+25 \% \text { RDP }\end{array}$ & 30.82 & 67.34 & 8.65 & 21.18 & 36.50 & 35.04 \\
\hline $\begin{array}{l}\text { T }_{8}: \text { RDF NK + } 75 \% \text { P through FBM } \\
+25 \% \text { RDP + PSB }\end{array}$ & 30.55 & 70.11 & 8.57 & 21.69 & 36.47 & 35.46 \\
\hline $\begin{array}{l}\text { T9: }_{9} \text { RDF NK + 100\% P through } \\
\text { FBM }\end{array}$ & 28.99 & 64.87 & 8.60 & 19.32 & 33.34 & 33.77 \\
\hline $\begin{array}{l}\text { T}_{10}: \text { RDF NK + } 100 \% \text { P through } \\
\text { FBM + PSB }\end{array}$ & 31.64 & 67.71 & 8.55 & 20.09 & 35.90 & 34.83 \\
\hline S.Em \pm & 2.22 & 2.47 & 0.40 & 0.79 & 1.11 & 3.33 \\
\hline CD@(0.05) & 6.54 & 7.33 & NS & 2.34 & 3.29 & NS \\
\hline
\end{tabular}

The effect of different treatments on stover yield is given in Table 4 . The stover yield was significantly affected by the application of FBM along with mineral fertilizer. Among different treatments, plot fertilized with 25 per cent of recommended $\mathrm{P}$ through FBM and remaining through mineral fertilizer with PSB seed treatment $\left(\mathrm{T}_{4}\right)$ was turned out to be significantly best treatment with stover yield of $43.73 \mathrm{q} \mathrm{ha}^{-1}$. Among all the remaining treatments $\mathrm{T}_{3}$ (RDF NK $+25 \% \mathrm{P}$ through $\mathrm{FBM}+75 \%$ RDP $)\left(42.19 \mathrm{q} \mathrm{ha}^{-1}\right), \mathrm{T}_{2}$ (RDF $\mathrm{NPK}+\mathrm{PSB})\left(41.65 \mathrm{q} \mathrm{ha}^{-1}\right)$ and $\mathrm{T}_{1}$ (RDF NPK) (40.67 q ha ${ }^{-1}$ ) remained on par with best treatment. Significantly lower stover yield was recorded with treatments $\mathrm{T}_{9}(33.34$ $\mathrm{q} \mathrm{ha} \mathrm{h}^{-1}$ ). The data on the effect of fish bone meal on grain and stover yield of soybean was presented in Table 4. It was evident from the results that the grain and stover yield of soybean was significantly influenced due to fish bone meal and mineral fertilizer application with or without PSB seed treatments. The treatment $\mathrm{T}_{4}(\mathrm{RDF} \mathrm{NK}+25$ $\% \mathrm{P}$ through $\mathrm{FBM}+75 \% \mathrm{RDP}+\mathrm{PSB})$ recorded significantly higher grains $(26.15 \mathrm{q}$ $\mathrm{ha}^{-1}$ ) and stover (43.73 $\mathrm{q} \mathrm{ha}^{-1}$ ) yield than the $\mathrm{T}_{9}$ and $\mathrm{T}_{10}$ treatments. The treatments $\mathrm{T}_{3}, \mathrm{~T}_{2}$, $\mathrm{T}_{1}$ and $\mathrm{T}_{6}$ were on par with each other. The minimum grain (19.32 $\mathrm{q} \mathrm{ha}^{-1}$ ) and stover (33.34 q ha $\mathrm{ha}^{-1}$ yield was recorded with treatment $T_{9}$. The greater availability of 
nutrients and better nodulation under the influence FBM resulted in better growth and development of plants. Ultimately it increased grain and stover yield in soybean as reported by Shehata and Khawas (2003), Salomonsson et al., (1995), Valenzuela et al., (2000), Jeng et al., (2004). Grain and stover yield of soybean was significantly influenced due to fish bone meal and mineral fertilizer application. This may be ascribed to increased $\mathrm{P}$ availability in soil due to applied $\mathrm{P}$ content as mineral fertilizer in initial days and through FBM-P in the later growth period. This intern influenced the physiological processes that are directly related to nitrogen fixation, photosynthesis and translocation of carbohydrates for pod growth. Phosphorus solubilising bacteria species like Pseudomonas striata are also reported to be beneficial in increasing the $\mathrm{P}$ availability in soil and thereby grain and stover yield of pulses (Gupta, 2006).

\section{Crude protein content}

Data furnished in Table 4 showed that the protein content in seed was not significantly affected by various treatments even though the maximum protein content was recorded with treatment $\mathrm{T}_{4}(\mathrm{RDF} \mathrm{NK}+25 \% \mathrm{P}$ through $\mathrm{FBM}+75 \% \mathrm{RDP}+\mathrm{PSB})(37.27 \%)$, which was relatively higher than the rest of the treatments. The result further revealed that the lowest protein content to the tune of 33.34 per cent in seed was recorded with treatment $\mathrm{T}_{9}$ (RDF NK + $100 \%$ P through FBM).

A statistically non-significant difference was observed for crude protein content of soybean due to application fish bone meal. The treatments $\mathrm{T}_{4}$ (RDF NK $+25 \% \mathrm{P}$ through $\mathrm{FBM}+75 \% \mathrm{RDP}+\mathrm{PSB})$ recorded comparablyhigh uptake of $\mathrm{N}$, which induced high crude protein content in $\mathrm{T}_{4}$ treatment than compared to other treatments. The Enhancement of protein content of soybean was due to higher uptake of nitrogen and phosphorus through slow and continuous supply of $\mathrm{N}, \mathrm{P}$ and $\mathrm{Ca}$ combinely due to $\mathrm{N}$ fixation and application of fish bone meal with inorganic fertilizers. Since phosphorus improves pod quality by regulating the photosynthesis, root enlargement and carbohydrate metabolism, thus they increased protein percentage in soybean seeds. Tanwar and Shaktawat (2003) found similar results. Singh et al., (2009) also reported the same trend of results.

In conclusion, higher soybean yields was noticed with the application of 25 per cent of recommended $\mathrm{P}$ through $\mathrm{FBM}$ and remaining through mineral fertilizer with PSB seed treatment compared to RDF or no fish bone meal applied treatments. Application of fish bone meal in combination with reduced mineral fertilizers can be used for sustainable nitrogen, phosphorus and calcium management in crop production under acidic soil conditions.

\section{References}

Chen, Y. P., Rekha, P. D., Arunshen, A. B., LAI, W. A. and Young, C. C., 2006, Phosphate solubilizing bacteria from subtropical soil and their tri-calcium phosphate solubilizing abilities. Appl. Soil Ecol.,34: 33-41.

Gaur, A. C. and Sunita, G., 1999, Rock phosphate availability and solubilization. A Review, Curr. Trends Life Sci., 23: 151-164.

Gupta, A., Sharma, V. K., Sharma, G. D. and Chopra, P., 2006, Effect of biofertilizers and phosphorus levels on yield attributes, yield and quality of urdbean (Vigna mungo). Indian J. Agron., 51(2): 142-144.

Jeng, A., Haraldsen, T. K., Vagstad, N. and Gronlund, A., 2004, Meat and bone meal as nitrogen fertilizer to cereals in 
Norway. Agric. Food Sci., 13: 268-275.

Kundu, R., Brahmachari, K. and Karmakar, S., 2010, Impact of different organic manures in enhancing the growth and productivity of rice (Oryza sativa) under coastal saline tract of West Bengal. J. Crop Weed, 6(2): 42-45.

Lee, K. J., Powell, M. S., Barrows, F. T., Smiley, S., Bechtel, P. and Hardy, R. W., 2010, Evaluation of supplemental fish bone meal made from Alaska seafood processing by-products and dicalcium phosphate in plant protein based diets for rainbow trout (Oncorhynchus mykiss). Aquaculture, 302(3): 248-255.

Madhavi, P., Ramaiah, N.V., Satyanarayana, V. and Vijay Kumar, B.M., 1997, Importance of different times of sowing and fertility levels on growth and yield of soybean [Glycine $\max (\mathrm{L}).] . \quad J$. Oilseed Res., 14(1): 109-110.

Pal, S., Brahmachari, K., Kundu, R. and Saha, S., 2010, Effect of fishmeal application on rice-based cropping sequence in coastal saline belts of West Bengal. Oryza, 47(1): 42-47.

Patil, S. H., Talashilkar, S. C. and Mehta, V. B., 2000, Integrated nutrient management using fish meal and fertilizers for rice (Oryza sativa). Indian J. Agric. Sci., 70(1): 31-33.

Salomonsson, L., Salomonsson, A., Olofsson, S. and Jonsson, A., 1995, Effects of organic fertilizers and urea when applied to winter wheat. Acta Agric.
Scand. B Soil Pl. Sci.,45(3): 171-180.

Salve, Y. V., Jadhav, A. S. and Lambade, B. M., 2010, Response of summer groundnut (Arachis hypogaea L.) with varying levels of phosphorus and potassium. J. Maharashtra Agric. Univ,35(2):178-183.

Singh, S. R., Ummed, S. and Singh, J. K., 2009, Effect of bioinoculants and FYM on growth, yield and quality of soybean [Glycine max (L.) Merril] under rainfed conditions of Kashmir valley. Ann. Agric. Res., 30(3): 87-90.

Shehata, M. M. and Khawas, S. A., 2003, Effect of two biofertiltzers on growth parameters, yield characters, nitrogenous components, nucleic acids content, minerals, oil content, protein profiles and DNA banding pattern of sunflower (Helianthus annuus L. cv. Vedock) yield. Pakistan J. Biol. Sci., 6: 1257-1268.

Tanwar, S. P. S. and Shaktawat, M. S., 2003, Influence of phosphorus sources, levels and solubilizers on yield, quality and nutrient uptake of soybean (Glycine max), Wheat (Triticum aestivum) cropping system in southern Rajasthan. Indian J. Agric. Sci., 73: 3-7.

Valenzuela, H. R., Goo, T., Hamasaki, R. H. and Radovich, T., 2000, The effect of bone meal on the yield of jicama, Pachyrhizuserosus, in Oahu Hawaii. Proceedings of the Florida State Horticultural Society, 113: 222-226.

\section{How to cite this article:}

Cheluvaraj, L.N., B.C. Dhananjaya, M. Ashok, H.K. Veeranna and Chidanandappa, H.M. 2020. Influence of Fish Bone Meal on Performance of Soybean (Glycine max L.) in Sandy Loam Soils of Chikkamagaluru District of Karnataka. Int.J.Curr.Microbiol.App.Sci. 9(10): 2297-2305. doi: https://doi.org/10.20546/ijcmas.2020.910.277 